\title{
Morphological Analysis of Neonates of Rats Treated with Dexamethasone in the Initial Phase of Pregnancy
}

\author{
Análisis Morfológico de Neonatos de Ratas Tratadas con Dexametasona en Fase Inicial de la Preñez \\ Paulo Estevão Araújo Vilaça Júnior; Álvaro Aguiar Coelho Teixeira; Valéria Wanderley Teixeira; \\ Eleonora de Figueiredo Moraes; Ana Cláudia Carvalho de Araújo \& Carina Scanoni Maia
}

VILAÇA JÚNIOR, P. E. A.; TEIXEIRA, A. A. C.; WANDERLEY-TEIXEIRA, V. ; MORAES, E. F.; ARAÚJO, A. C. C. \& MAIA, C.S. Morphological analysis of neonates of rats treated with dexamethasone in the initial phase of pregnancy. Int. J. Morphol., 26(3):523$527,2008$.

SUMMARY: The glucocorticoid dexamethasone has been largely used due to its anti-inflammatory effect. However, several authors report that the excessive exposition to it during pregnancy may cause a retard in the development in several tissues, mainly: liver, lungs and kidneys. But, the majority of the works are done with the application of dexamethasone in the late periods of pregnancy. Because of the lack of researches that evaluate the effects in the beginning of gestation, this paper aimed at evaluating the effect of dexamethasone administered in the initial phase of pregnancy, over the morphology of neonates rat. It was used 10 albino rats (Rattus norvegicus albinus) aged 90 days from the lineage Wistar. The female were coupled and divided in two groups: Group I - rats not submitted to the dexamethasone application (control); Group II - rats submitted to the dexamethasone application in the first 5 days of pregnancy. The results show that the treatment with dexamethasone in a dosage of $0.8 \mathrm{mg} / \mathrm{Kg}$ during the 5 first days of pregnancy does not produces a weight and height reduction or malformation in the offspring, it does not cause changes in the development of the liver and kidneys of neonate rats, but it leads to a reduction in the denseness of the interalveolar septa causing a higher distension of the alveoli.

KEY WORDS: Pregnancy; Dexamethasone; Histology; Rats.

\section{INTRODUCTION}

The glucocorticoids can be applied in the treatment of and endless number of diseases such as: allergies, immunomediated diseases, septal shock, cardiogenic shock, central nerve system traumatism and vertebral column traumas. It has been also used in the therapeutical hormonal reposition, in cases of supra-renal dysfunction and, recently, it has been associated to other medicines to integrate anticancer treatments (Fonseca et al., 2002; Bavaresco et al., 2005).

Among the glucocorticoids the dexamethasone has become very popular, being more commonly employed as an auxiliary in anticancer treatments. The relatively big affinity by membrane receptors, the elevated antiinflammatory potential, the extensive half-life of the drug and its influence in calcium metabolism, reducing water retention and edema formation are some of the characteristics that attributes a certain predilection by the use of dexamethasone in these treatments (Bavaresco et al.).
Other situations in which it is common to employ the dexamethasone use are the cases of gestation with risks of prematurity. The pre-natal application of the drug happens in order of accelerate the development of certain tissues and organs of the fetus, making, thus, it possible and increase in the probability of premature survival and avoiding or minimizing some complications originated from prematurity (Al-Dahan et al., 1987; Ghosh et al., 2000; Souza et al., 2001; Bruder et al., 2006).

Studies with rodents, with the application of dexamethasone during gestation, have demonstrated some destructive effects over the embrionary development, such as: high number of re-absorptions, implantations of unviable embryos and implantation of affected embryos. Other abnormalities from morphogenic order as palatal fissure, labial fissure and reduced size of the concepts have been reported in studies that employ the pre-natal administration of this glucocorticoid (Hansen et al., 1999; Ghosh et al.). 
The literature reports that the glucocorticoids can intervene in the development of several tissues, presenting a higher influence in organs as the liver, the lungs and the kidneys. Over the tissue of these organs the dexamethasone may lead to a modification in the patterns of insulin activity, changes in the plasmatic and tissular lipidic profile and changes in the patterns of proliferation, differentiation and cellular deaths (Salhanick et al., 1983; Martins et al., 2003; Scavo et al., 2003; Theogaraj et al., 2005).

Recently, some studies have been done to verify the reliability of pre-natal application of corticosteroid hormones and the extension of harmful effects unchained by the exposition of the embryonary tissues. A considerable number of experiments has been done to evaluate the action of dexamethasone over late pregnancy phases in female rats. However, experiments that evaluate the corticotherapy over the initial phases of pregnancy are still scarce (Hansen et al.; Fonseca et al.).

Due to the fact that experimental tests which approach the implications of excessive exposition of embryonary tissues to dexamethasone, in the initial phases of pregnancy are still incipient, the present study had the objective of evaluating the effect of the dexamethasone, administered in the initial phase of pregnancy over the number, size and weight of the young animals, besides the histology of the liver, kidneys and lungs of these neonates.

\section{MATERIAL AND METHOD}

It was used 10 albino rats (Rattus norvegicus albinus) aged 90 days, virgins, weighing nearly $200 \mathrm{~g}$, from the lineage Wistar, from the Biotery of the Department of Morphology and Animal Physiology from the Federal Rural University of Pernambuco. The animals were confined in cages and kept with meal and water "ad libitum", temperature of $22^{\circ} \mathrm{C}$ and photoperiod of 12 hours clear and 12 hours dark. The animals were divided in two groups:

Group I - rats not submitted to the dexamethasone application (control);

Group II - rats submitted to the application of dexamethasone in the five first days of pregnancy.

The dexamethasone was administered intraperitoneal in a dosage of $0.8 \mathrm{mg} / \mathrm{Kg}$ (Cruz et al., 1996). The pregnant females from group I and II were accompanied during all the gestation until the birth of the young animals, which were counted, weighed and measured, being after euthanized for histological analysis (macro and microscopically). The macroscopically analysis was made through the observation of some visible malformation and the change in weight and size of the young animals. For the microscopic analysis, fragments from the liver, the kidneys and the lungs were removed, which were fixed in Boüin liquid and processed for inclusion in paraffin. The cuts were submitted to dyeing by hematoxilin-eosin. It was observed the stages of development of these organs because they are the most affected in the offspring when the rats are treated with dexamethasone during gestation (Dearden \& Mosier, 1988; Ghosh et al.; Martins et al., 2003). The averages of number, weight and size of the young animals were submitted to the non-parametric test of Mann-Witney with 95\% of significance.

\section{RESULTS}

In Table 1 are the data related to the averages of number, weight and size of the neonates of the experimental groups. After statistical analysis it was verified that there were not differences between the treatments. Also, abortions and mal-formation in the head, trunk and members of the neonates were not observed.

Table I. Averages of number, weight and size of the neonates from the experimental groups.

\begin{tabular}{lccc}
\hline & \multicolumn{3}{c}{${ }^{1}$ Average \pm Standard deviation } \\
\hline Groups & $\mathrm{N}^{\mathrm{o} .}$ of neonates & Weight $(\mathrm{g})$ & Size $(\mathrm{cm})$ \\
I & $12.00 \pm 2.55 \mathrm{a}$ & $6.16 \pm 0.65 \mathrm{a}$ & $6.21 \pm 0,34 \mathrm{a}$ \\
II & $10.40 \pm 2.07 \mathrm{a}$ & $6.20 \pm 0.48 \mathrm{a}$ & $6.52 \pm 0.36 \mathrm{a}$ \\
\hline
\end{tabular}

${ }^{1}$ Averages followed by the same letters do not differ statistically between them by Mann-Witney $(\mathrm{P} \leq 0,05)$.

The liver and the kidneys of the neonates from group II presented the same histological characteristics observed in the neonates from group I (Figs. 1, 2 and 3). However, the lungs of the neonates from group II presented well developed with numerous alveoli with varied diameter and interalveolar septa very lean, indicating an increase in the maturity of these structures. The populations of pneumocytes I and II are present as well as the cells from the dust (Figs. 4, 5 and 6).

\section{DISCUSSION}

The results of the present research showed that the treatment with dexamethasone in the dosage $0,8 \mathrm{mg} / \mathrm{dia} / \mathrm{ani}$ mal administered in the 5 first days of pregnancy does not induce abortions, malformations or meaningful differences 


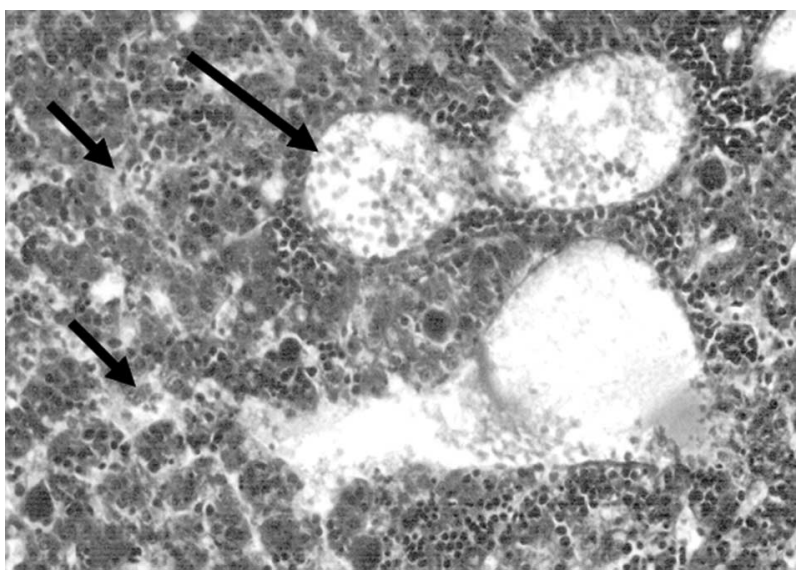

Fig. 1. Neonate liver of from group II. Center-lobular vein (long arrow) and sinusoid capillaries (short arrows). H-E. 214X.

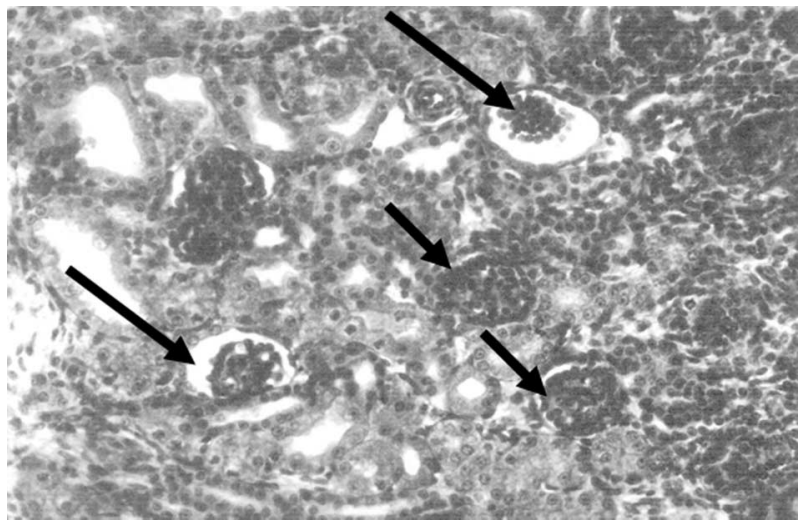

Fig. 3. Neonate kidney of group II. Developed glomeruli (long arrows) and developing glomeruli (short arrows). H-E. 214X.

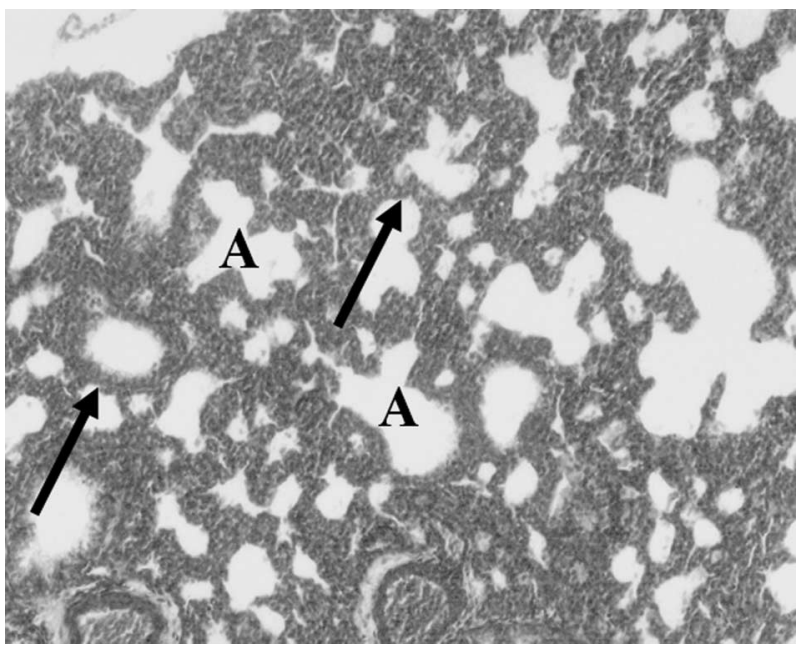

Fig. 5. Lung of neonate from group I. Alveoli (A) a little developed and dense interalveolar septa (arrows). H-E. 1071X.

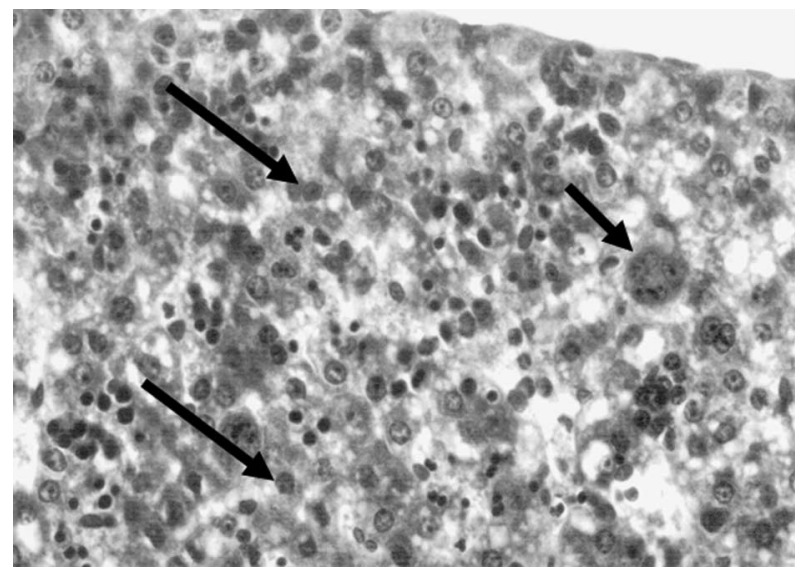

Fig. 2. Hepatocytes (long arrows) and hematopoietic cell (short arrow). H-E. 428X.

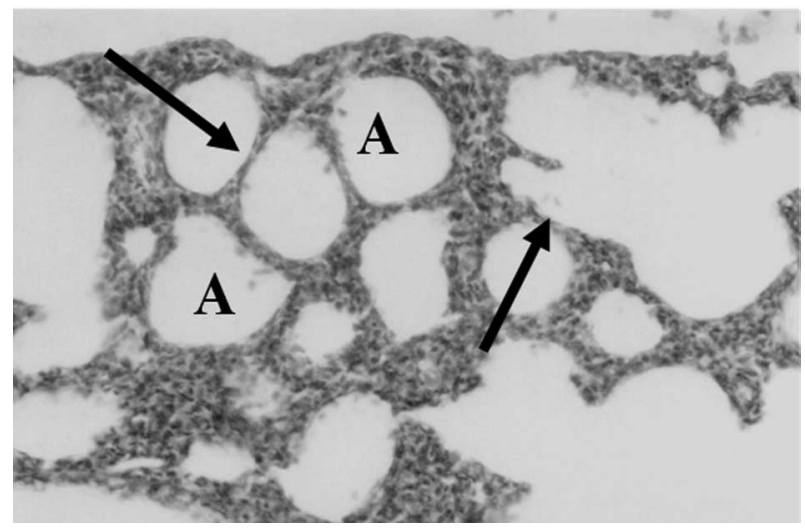

Fig. 4. Lung of neonate from group II. Alveoli (A) well developed and lean alveolar septa (arrows). H-E. 428X.

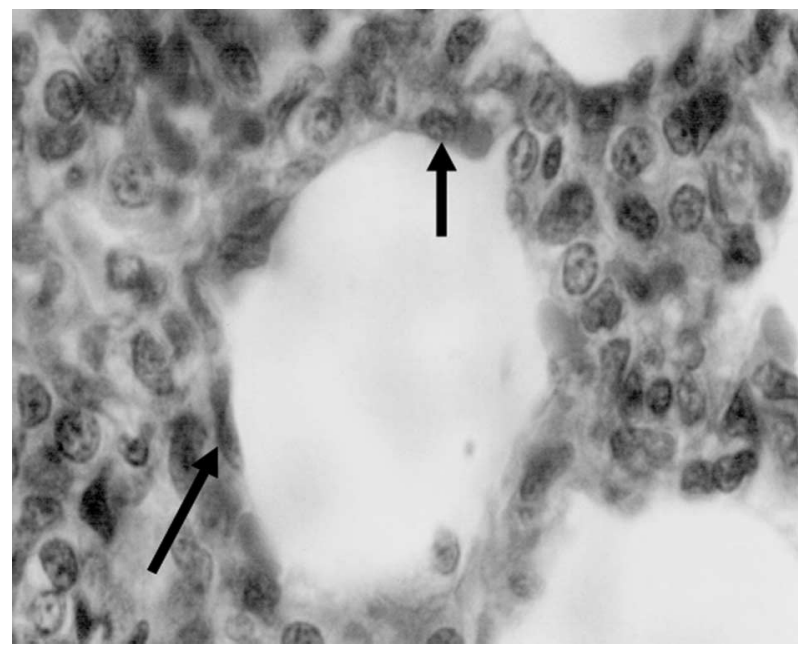

Fig. 6. Pneumocytes I (long arrow) and II (short arrow). H-E. 1071X 
in number, weight and size of the neonates when compared to the control group. This fact may be related to the existence of a mechanism of regulation of the entry of the dexamethasone in the placental tissue because, according to Waddel et al. (1998) this regulation would be done by the enzyme action 11b-HSD type 1 and 2 that would regulate the action of the glucocorticoids, the first amplifying and the second softening the action of these hormones over the fetal tissue.

Yet we should call attention to the fact that during the gestation of rodents the enzyme 11b-hydroxysteroid dehydrogenas type 1 does not represent bioactivity in the placenta during the initial gestational periods and the expression of its codifying genes increase throughout the gestation, while the protein from type 2 presents an initial bioactivity that decreases throughout the gestation. This suggests that exist a higher permissively of the placenta to the entrance of glucocorticoid hormones (Waddel et al.; Seckl, 2004).

Regarded to the histological aspects of the liver and kidneys the results did not show changes in the structural level of the neonates from group I. These findings are according to the literature that points out for the existence of gestational periods of higher susceptibility to glucocorticoids that would be related to the variation in the level of the enzymes 11b-HSD type 1 and 2 during the gestation (Laborde et al.,1992; Oue et al., 2000; Nevagi \& Kaliwal, 2001; Seckl).

In the lungs of the neonates from group treated, changes in the alveolar portions were observed related to the reduction of the denseness of the interalveolar septum. These alterations determine an increase of respiratory surface. According to Cole, (1995); Oue et al. and Seckl \& Walker (2001) reports the antenatal treatment with dexamethasone, in the initial phases of gestation, produces in the lungs of the neonates an increase of the synthesis of 11b-HSD from type 1 , whose action of $11 \mathrm{~b}$ - redutase would amplify the glucocorticoid activity on this tissue. The influence of the dexamethasone on the maturation of the lungs tissue is largely known and constitutes, yet, a therapeutical option (Oue et al.; Okajima et al., 2001). Thus, we conclude that the treatment with dexamethasone in the dosage of $0.8 \mathrm{mg} / \mathrm{ml} /$ animal during the 5 days of pregnancy does not produces the reduction of weight, size or malformation in the offspring, it does not cause changes in the development of the liver and kidneys in the neonate rats, but it leads to a reduction in the denseness of the interalveolar septa causing a higher distension in the alveoli.

VILAÇA JÚNIOR, P. E. A.; TEIXEIRA, A. A. C.; WANDERLEY-TEIXEIRA, V.; MORAES, E. F.; ARAÚJO, A.C. C. \& MAIA, C. S. Análisis morfológico de neonatos de ratas tratadas con dexametasona en fase inicial de la preñez. Int. J. Morphol., 26(3):523-527, 2008.

RESUMEN: El glucocorticoide dexametasona ha sido ampliamente utilizado en virtud de su potencial antiinflamatorio. Sin embargo, varios autores relatan que la exposición excesiva a la dexametasona durante la preñez puede causar el retardo del desarrollo de varios tejidos, principalmente hígado, pulmones y riñones. La mayoría de los trabajos son llevados a cabo con la aplicación de dexametasona en los períodos tardíos de la gestación. El objetivo del trabajo fue evaluar el efecto de la dexametasona, sobre la morfología de ratones neonatos, administrada en la fase inicial de la preñez. Fueron utilizadas 10 ratas Wistar albinas (Rattus norvegicus albinus) con 90 días de edad. Las hembras fueron apareadas y divididas en dos grupos: Grupo I- ratas no sometidas a la dexametasona (grupo control) y Grupo II - ratas sometidas a la aplicación de dexametasona durante los cinco primeros días de preñez. Los resultados mostraron que el tratamiento con dexametasona en dosis de $0,8 \mathrm{mg} / \mathrm{Kg}$, a lo largo de los cinco primeros días de la preñez, no produce reducción de peso, longitud o malformación en la prole, tampoco causa alteraciones en el desarrollo del hígado y riñones en los ratones neonatos, pero sí reduce el grosor de los septos interalveolares, causando de esta manera, mayor distensión de los alvéolos.

PALABRAS CLAVE: Preñez; Dexametasona; Histología; Ratas.

\section{REFERENCES}

Al-Dahan, J.; Stimmler, L.; Chantler, C. \& Haycock, G. B. The effect of antenatal dexamethasone administrtioan on gromerular filtration rate and renal sodium excretion in premature infants. Pediatr. Nephrol., 1(2):131-5, 1987.

Bavaresco, L.; Bernardi, A. \& Battastini, A. M. O. Glicocorticóides: Usos clássicos e emprego no tratamento do câncer. Infarma, 17(7/9):58-60, 2005.
Bruder, E. D.; Ping, C. L. \& Raff, H. Metabolic consequences of hypoxia from birth and dexamethasone treatment in the neonatal rat: Comprehensive hepatic lipid and fatty acid profiling. Endocrinology. 145(11):5364-72, 2006.

Cole, T. J. Cloning of the mouse 11beta-hydroxysteroid dehydrogenase type 2 gene: tissue specific expression and localization in distal convoluted tubules and 
collecting ducts of the kidney. Endocrinology, 136:4693-6, 1995.

Cruz, F. C. M.; Smaniotto, S. \& Simões, M. J. Morphological aspects of the cervical mucosa of persistent estrous rats under action of estrogen and/or dexametasone. Br. J. Morphol. Scie., 13(1):100, 1996.

Dearden, L. C. \& Mosier, H. D. Ultrastructure of rat fetal lung after various glucocorticoid treatments. An. Anat. Norm., 6(6):146-50, 1988.

Fonseca, C. S.; Viloria, M. I. V. \& Repetti, L. Alterações fetais induzidas pelo uso de antiinflamatórios durante a gestação. Ciencia Rural, 32(3):529-34, 2002.

Ghosh, B.; Wood C. R.; Held, G. A.; Abbott, B. D. \& Lau, C. Glucocorticoid receptor regulation in the rat embryo: a potential site for developmental toxicity? Toxicol. Appl. Pharmacol., 164(2):221-9, 2000.

Hansen, D. K.; Laborde, J. B.; Wall, K. S.;Holson, R. R. \& Young, J. F. Pharmacokinetic considerations of dexamethasone-induced developmental toxicity in rats. Toxicol. Sci., 48:230-9, 1999.

Laborde, J. B.; Hansen, D. K.; Young, J. F.; Sheeham, D. M. \& Holson, R. R. Prenatal dexamethasone exposure in rats: Effects of dose, age at exposure, and druginduced hypophagia on malformations and fetal organ weights. Toxicol. Sci., 19(4):545-54, 1992.

Martins, J. P.; Monteiro, J. C. \& Paixão, A. D. Renal function in adult rats subjected to prenatal dexamethasone. Clin. Exp. Pharmacol. Physiol., 30(1/2):32-7, 2003.

Nevagi, S. A. \& Kaliwal, B. B. Effect of dexamethasone on implantation and pregnancy in albino rats. Indian J. Exp. Biol., 39(11):1163-5, 2001.

Okajima, S.; Matsuda, T.; Cho, K.; Matsumoto, Y.; Kobayashi, Y. \& Fujimoto, S. Antenatal dexamethasone administration impairs normal postnatal lung growth in rats. Pediatr. Res., 49(6):777-81, 2001.

Oue, T.; Shima, H.; Guarino, N. \& Puri, P. Antenatal dexamethasone administration increases fetal lung DNA synthesis and RNA and protein content in nitrofeninduced congenital diaphragmatic hernia in rats. Pediatr. Res., 48(6):789-93, 2000.

Salhanick, A. I.; Krupp, M. N. \& Amatruda, J. M. Dexamethasone stimulates insulin receptor synthesis in cultured rat hepatocytes. J. Biol. Chem., 258(23):14130$5,1983$.

Scavo, L. M.; Newman, V.; Ertsey, R.; Chapin. C. J. \& Kitterman, J. A. Maternally administered dexamethasone transiently increases apoptosis in lungs of fetal rats. Exp. Lung. Res., 29(4):211-26. 2003.

Seckl, J. R. Prenatal glucocorticoids and long-term programming. Eur. J. Endocrinol., 151(3):49-62, 2004.

Seckl, J. R. \& Walker, B. R. Minireview: 11betahydroxysteroid dehydrogenase type 1- a tissue-specific amplifier of glucocorticoid action. Endocrinology, 142(4):1371-6, 2001.

Souza, E.; Kobayashi, S.; Camano, M. J. S. L. \& KulayJúnior, L. Ação da betametasona em ratas prenhes: Impacto sobre os níveis de corticosterona e glândulas adrenais maternas e fetais. Rev. Bras. Ginecol. Obstet., 23(10):667-73, 2001.

Theogaraj, E.; John, C. D.; Christian, H. C.; Morris, J. F.; Smith, S. F. \& Buckingham, J. C. Perinatal glucocorticoid treatment produces molecular, functional, and morphological changes in the anterior pituitary gland of the adult male rat. Endocrinology, 146(11):4804-13, 2005.

Waddel, B.; Benediktsson, R.; Brown, R. \& Seckl, J. R. Tissue-specific mRNA expression of 11B-hydrosteroid dehydrogenase types 1 and 2 and the glucocorticoid receptor within rat placenta suggest exquisite local control of glucocorticoid action. Endocrinology, 139:157123, 1998.

Correspondence to:

Prof. Dr. Valéria Wanderley Teixeira.

Universidade Federal Rural de Pernambuco.

Departamento de Morfologia e Fisiologia Animal.

Área de Histologia

Rua Dom Manoel de Medeiros s/n - Dois Irmãos

CEP: $52.171-900$

Recife-PE

BRAZIL

Email: valeria@dmfa.ufrpe.br

Received: 05-12-2007

Accepted: 07-07-2008 
